\title{
Studi Hasil Bimbingan Teknis Pengembangan Perangkat Pembelajaran Berbasis Keterampilan Abad-21 dalam Rangka Penerapan Program Merdeka Belajar
}

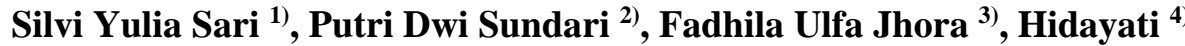 \\ 1) 2) ${ }^{4}$ Pendidikan Fisika, Jurusan Fisika, Universitas Negeri Padang \\ ${ }^{3)}$ Fisika, Jurusan Fisika, Universitas Negeri Padang \\ silviyuliasari@fmipa.unp.ac.id
}

\begin{abstract}
The education process in schools should be able to increase mastery of science and technology and provide training and science process skills that can improve the quality of human resources. Education is the main key to modernization and progress for a nation. In reality, $4 \mathrm{C}$ learning on $21^{\text {st }}$ century skills has not been fulfilled properly. This needs to be addressed starting by develop a learning material such as lesson plans. This activity aims to improve competency of teachers in developing lesson plan. The subject was the teachers in SMPN 2 Baso, Agam district. The methods used are presentation and discussion, group work, independent task, and task presentation. Instruments to collect the data consist of knowledge test. Data analysis techniques were descriptive statistical analysis and paired sample t-test. The result of this assisting is the implementation of assisting on the writing of lesson plan is effective to improve the $21^{\text {st }}$ century skills and independent learning program in school of teachers.
\end{abstract}

Keywords : lesson plan, independent learning program, 21st century skills

This is an open access article distributed under the Creative Commons 4.0 Attribution License, which permits unrestricted use, distribution, and reproduction in any medium, provided the original work is properly cited. $\odot 2018$ by author and Universitas Negeri Padang.

\section{PENDAHULUAN}

Pembelajaran pada abad 21 menuntut pencapaian keterampilan abad 21 pada peserta didik. Pencapaian ini tentunya dapat diwujudkan melalui proses perencanaan, pelaksanaan, dan evaluasi pembelajaran yang berbasis kepada keterampilan tersebut. Kegiatan perencanaan ini tergambar dari perangkat pembelajaran yang digunakan sekolah untuk menyelenggarakan proses pembelajaran di kelas, mulai dari silabus, RPP, bahan ajar, media pembelajaran yang digunakan, serta instrumen penilaian yang akan digunakan. Seluruh aspek perangkat pembelajaran ini hendaknya disusun berorientasi pada kebutuhan keterampilan abad 21 yang akan dicapai.

Bentuk perencanaan yang matang yang tertuang dalam perangkat pembelajaran ini menjadi dasar dan panduan dalam menyelenggarakan pembelajaran di kelas sehingga tidak melenceng dari kompetensi dan tujuan pembelajaran yang akan dicapai. Kompetensi abad-21 mencakup suatu pengertian yang luas terfokus pada pengetahuan, sikap, dan keterampilan yang ditekankan pada apa yang dibutuhkan siswa di sekolah, dunia kerja, dan kehidupan mereka (Bamalli, 2013; Chen, 2017) sesuai dengan Revolusi Industri 4.0.

Tuntutan pada era revolusi industri $4.0 \mathrm{ini}$ menjadi tugas besar bagi pemerintah khususnya sektor pendidikan (Hendra, 2017). Peningkatan mutu dan kualitas pendidikan saat ini menjadi prioritas utama agar menghasilkan sumber daya manusia yang kompeten untuk menghadapi globaliasi (Baro'ah, 2020). Salah satu usaha pemerintah untuk meningkatkan mutu dan kualitas pendidikan ialah membuat kebijakan baru terkait kurikulum.

Kurikulum yang saat ini dicanangkan oleh pemerintah khususnya menteri pendidikan adalah kurikulum merdeka belajar. Konsep kurikulum merdeka belajar ini menekankan pada pemberian kebebasan di bidang pendidikan (Faiz dan Kurniawaty, 2020). Dalam hal ini, guru berperan sebagai fasilitator bagi siswa dalam memberikan pembelajaran (Mualifah, 2013)

Salah satu wujud nyata dalam perbaikan mutu ini adalah dengan keluarnya kebijakan tentang penyederhanaan RPP sebagai salah satu bagian dari perangkat pembelajaran. Penyederhanaan ini bertujuan agar guru tidak terfokus pada urusan administrasi di sekolah, 
tetapi juga fokus dalam mengoptimalkan mutu pembelajaran yang akan di berikan kepada peserta didik.

SMP Negeri 2 Baso merupakan salah satu sekolah yang telah menerapkan kurikulum dalam pembelajaran. Sekolah ini telah berdiri sejak tahun 1984 dan memiliki akreditasi B. Fasilitas sekolah ini cukup lengkap dengan adanya ruang kelas yang banyak, mushala, laboratorium IPA, dan ruang komputer. Akan tetapi, peningkatan peserta didik baik dari segi kuantitas maupun kualitas tidak sejalan dengan meningkatnya pembangunan di sekolah ini. Hal ini dapat diamati langsung di sekolah dan berdasarkan observasi dan diskusi dengan kepala sekolah. Jumlah siswa di sekolah ini semakin menurun setiap tahunnya.

Pada tahun 2019, jumlah siswa yang mengikuti UN hanya 12 orang saja. Adapun nilai UN siswa SMP Negeri 2 Baso yang diperoleh dari Puspendik Kemdikbud dapat diamati Gambar 1.

Grafik Rerata Nilai

TAHUN PELAJARAN 2018/2019

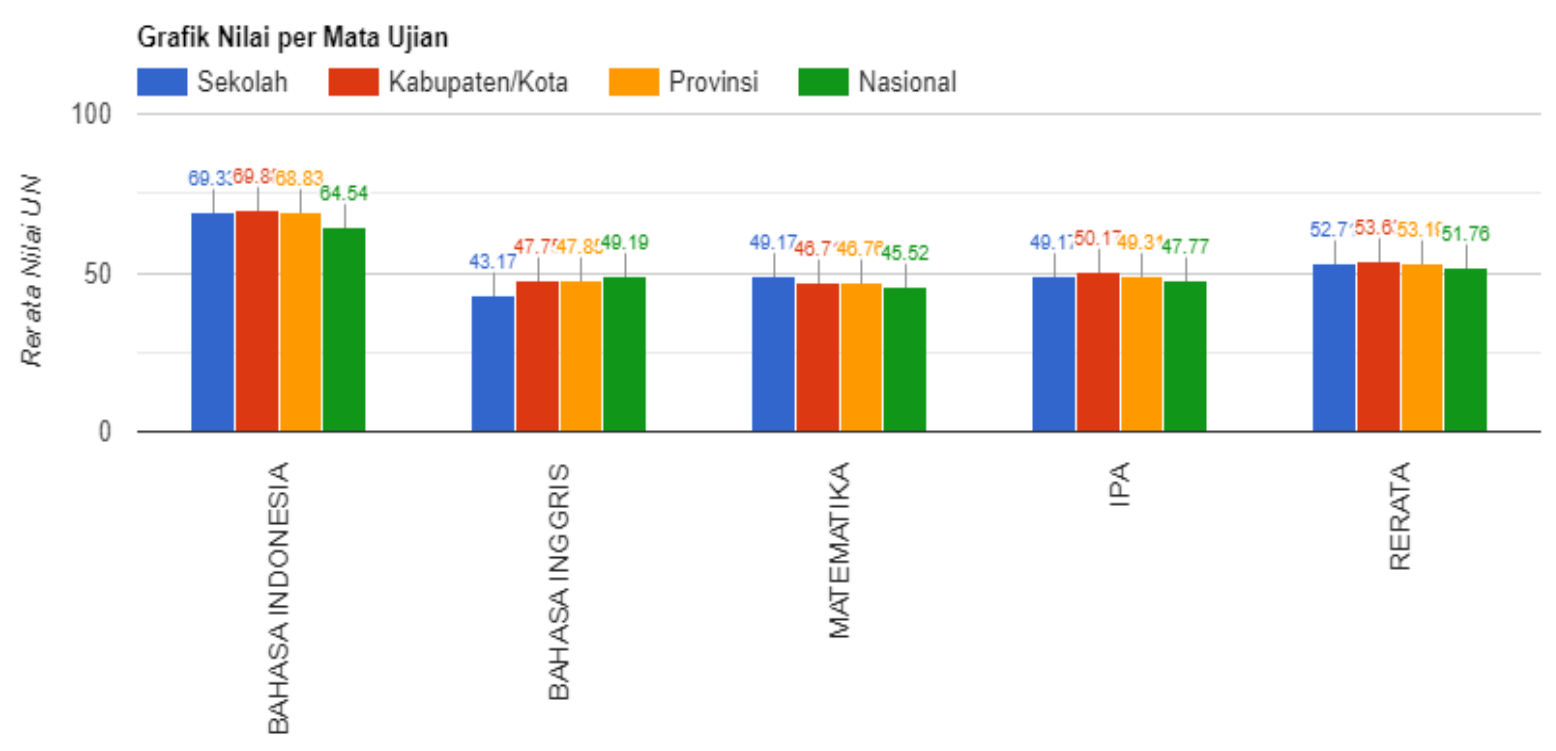

Gambar 1. Nilai UN siswa SMP Negeri 2 Baso Tahun 2018/2019

Grafik yang disajikan pada Gambar 1 merupakan nilai rata-rata UN dengan jumlah siswa sebanyak 12 orang. Berdasarkan data yang disajikan dapat diamati bahwa nilai rata-rata UN adalah 52,71 yang berada pada kategori kurang. Sebaran nilai siswa berada pada rentangan 40,01 sampai 65,00 . Hal ini menunjukkan rendahnya kompetensi yang dimiliki oleh siswa.

Berdasarkan diskusi dengan kepala sekolah dan beberapa orang guru bidang studi, rendahnya nilai siswa merupakan imbas dari rendahnya motivasi dan partisipasi aktif siswa selama proses pembelajaran. Penerapan kurikulum 2013 belum dilaksanakan secara ideal. Selain itu, perangkat pembelajaran yang merupakan aspek penting dalam mengontrol aktivitas pembelajaran belum dikembangkan dengan memperhatikan keterampilan- keterampilan yang harus dimiliki oleh siswa dalam penerapan kurikulum 2013.

Hasil observasi dan wawancara yang dilaksanakan dengan guru menunjukkan bahwa selama ini kegiatan pembelajaran di kelas tidak sesuai dengan RPP yang telah dirancang. RPP lebih di arahkan untuk pemenuhan tugas administratif guru setiap semester. Hal ini ditandai dengan pembelajaran di kelas yang tetap berpusat kepada guru dengan guru sebagai pemberi informasi utama. Menurut guru, hal ini dilakukan agar pembelajaran bisa tercapai sesuai dengan waktu yang ditetapkan, karena pelaksanaan pembelajaran sesuai dengan RPP yang telah dirancang cenderung membuat pembelajaran lebih lama. Selain itu, latar belakang siswa yang cenderung pasif membuat pembelajaran sulit dilaksanakan sesuai dengan langkah pembelajaran dalam RPP. 
Perencanaan pembelajaran yang tertuang dalam RPP kini belum mampu memenuhi tuntutan pembelajaran abad-21. Masalah yang terjadi di lapangan, guru masih belum paham benar RPP abad-21 tersebut. Sehingga masih saja mendownload RPP dari internet dan menggunakannya di kelas (Ahmad, 2020). Kurangnya pemahaman guru terkait pengin tegrasian keterampilan abad-21 ke dalam RPP juga menjadi suatu masalah yang dihadapi. Penyusunan perangkat pembelajaran yang mengintegrasikan keterampilan abad-21 harus memfasilitasi empat hal, salah satunya adalah 4C yaitu critical thinking, creative, collabo ration, dan communication (Trilling dan Fadel, 2009).

Berdasarkan pengamatan dan diskusi yang dilakukan di SMP Negeri 2 Baso Kabupaten Agam Sumatera Barat, peneliti mengidentifikasi beberapa permasalahan dalam pembelajaran. Permasalahan yang dihadapi oleh guru-guru antara lain rendahnya kompetensi dan keterampilan 4C siswa, guru belum mengem bangkan perangkat pembelajaran berbasis keterampilan abad 21, dan pembelajaran belum mengikuti langkah-langkah yang disusun dalam perangkat.

Langkah-langkah pembelajaran yang disusun dalam RPP belum memuat salah satu keterampilan abad 21. Langkah pembelajaran dibuat secara garis besar untuk kegiatan pendahuluan, kegiatan inti, dan kegiatan penutup. Kegiatan ini didominasi dengan penjelasan materi oleh guru, pemberian latihan atau tugas, dan tindak lanjut untuk pertemuan berikutnya. Keterlibatan aktif siswa dalam pembelajaran tidak tergambar dalam langkahlangkah pembelajaran yang dirancang.

Selanjutnya, guru mengalami kesulitan dalam membuat RPP satu lembar karena adanya beragam format yang ditemukan di internet. Selain itu, kesulitan dialami guru dalam menuliskan langkah pembelajaran berbasis keterampilan abad 21 di dalam RPP karena kurangnya informasi terkait berai keerampilan tersebut dan bentuk nyatanya dalam RPP. Hal ini berimbas pada pembelajaran yang tidak mengarah pada keterampilan abad 21.

Solusi yang dilakukan dalam menyelesaikan masalah ini adalah dengan mengembangkan perangkat pembelajaran yang berbasis keterampilan abad 21. Keterampilan ini berperan dalam meningkatkan perekonomian dan daya saing di era revolusi industri 4.0
(Zubaidah, 2019). Keterampilan dan sikap abad 21 digolongkan sebagai ways to thinking, ways to learning, dan ways to learning with other (Griffin \& Care, 2015). Selanjutnya, US-based Partnership for 21st Century Skills (P21), mengidentifikasi kompetensi yang diperlukan untuk abad 21 terdiri dari Critical Thinking Skills, Creative Thinking Skills, Communication skills, dan Collaboration skills (4C). Keterampilan abad 21 yang dimaksud dalam kegiatan ini adalah keterampilan $4 C$.

Keterampilan abad 21 membantu siswa untuk menalar, memahami menganalisis, dan menyelesaikan masalah melalui keterampilan berpikir kritis. Selanjutnya, kemampuan berkolaborasi akan membantu siswa untuk bekerja sama, beradaptasi dalam berbagai peran dan tanggungjawab, dan bekerja secara produktif dengan yang lain. Siswa juga dilatih untuk berkomunikasi yang baik secara lisan maupun tulisan. Selain itu, siswa juga dilatih untuk mengemukakan dan melaksanakan ide-ide yang inovatif (Riyanto, 2018).

Guru merupakan salah satu unsur penting yang memiliki peranan dalam meningkatkan kualiatas pembelajaran. Selain memiliki keterampilan abad-21, guru juga harus mampu mengembangkan perangkat pembelajaran yang dapat mengintegrasikan keterampilan abad-21 di dalamnya (Seperfine, 2008).

Pengembangan perangkat pembelajaran berbasis keterampilan abad $214 C$ merupakan salah satu upaya dalam penerapan program merdeka belajar. Empat program pokok kebijakan pendidikan Merdeka Belajar meliputi kebijakan baru Ujian Sekolah Berstandar Nasional (USBN), ujian nasional, penyeder hanaan Rencana Pelaksanaan Pembelajaran (RPP), dan kebijakan Penerimaan Peserta Didik Baru (PPDB) (Riyanto, 2019). Penyederhanaan berdasarkan Surat Edaran No. 14 Tahun 2019 dengan tetap memperhatikan keterampilan yang diperlukan pada abad 21 dan menginteg rasikannya dalam perangkat yang dibuat. Dengan demikian, diharapkan pembelajaran akan lebih terfokus pada pencapaian kompetensi dan keterampilan 4C dengan adanya perencanaan yang tertata secara sistematis dalam perangkat pembelajaran yang digunakan oleh guru.

Guru memiliki kewajiban untuk dapat mengembangkan perangkat pembelajaran, salah satunya adalah RPP sesuai dengan perkembangan siswa (Baro'ah, 2020). Awalnya 
RPP mencakup lebih dari sepuluh komponen di dalamnya. Namun, kini sesuai Surat Edaran Kemendikbud Nomor 14 Tahun 2019, RPP hanya memiliki 3 komponen utama yaitu tujuan pembelajaran, kegiatan pembelajaran dan penilaian. Kebijakan ini meringankan tugas guru dalam administrasi yang rumit namun tetap memperhatikan perkembangan siswa.

Pembelajaran yang efektif dapat tercapai dengan penyusunan pembelajaran yang matang sesuai tuntutan abad-21 (Meylani, Putra, dan Ardiansyah, 2018). Pengembangan perangkat pembelajaran ini dilakukan sebagai wujud penyelenggaraan pendidikan yang interaktif, memotivasi siwa, serta memberikan ruang bagi siswa untuk berkreasi dan mandiri sesuai dengan perkembangan psikologi siswa (Afriani, 2016). Mengingat pentingnya perangkat pembelajaran dalam menentukan keberhasilan proses pembelajaran dan keterampilan-keterampilan yang harus dikuasai siswa dalam menghadapi era revolusi industri 4.0, maka diperlukan suatu kegiatan pengembangan perangkat pembelajaran berbasis keterampilan abad-21.

Berdasarkan identifikasi masalah yang ada, solusi yang ditawarkan adalah kegiatan bimbingan teknis pengembangan perangkat pembelajaran berbasis keterampilan abad-21 bagi guru-guru. Dari paparan latar belakang yang telah disampaikan. Terdapat dua rumusan masalah yang harus diselesaikan. Pertama, bagaimana pengetahuan guru terkait program kurikulum merdeka belajar dan keterampilan abad-21?. Kedua, bagaimana keterampilan guru dalam mengintegrasikan keterampilan $4 \mathrm{C}$ dalam mengembangkan perangkat pembelajaran?

\section{METODE PENELITIAN}

Jenis penelitian yang dilakukan adalah penelitian eksperimen semu. Desain penelitian yang digunakan adalah one group pretestposttest design. Sampel penelitian ini adalah guru-guru di SMP Negeri 2 Baso Kabupaten Agam Sumatera Barat. Jumlah sampel dari penelitian ini adalah 14 orang guru-guru bidang studi. Penelitian ini bertujuan untuk menghasilkan RPP berbasis keterampilan 4C dan melihat peningkatan pengetahuan guru terhadap keterampilan abad 21. Instrumen yang digunakan dalam penelitian ini berupa lembar pretest dan posttest.

Kegiatan bimbingan dan teknis pengem bangan perangkat pembelajaran berbasis keterampilan 4C dilaksanakan melalui empat tahap, yaitu tahap observasi dan diskusi, tahap persiapan pelaksanaan, tahap pelaksanaan, dan tahap evaluasi pelaksanaan bimbingan dan teknis.

\section{Tahap Observasi dan Diskusi}

Tahap ini diawali dengan melakukan penjajakan dan penentuan lokasi kegiatan serta penyusunan rencana jadwal kegiatan. Kegiatan yang dilakukan meliputi obsevasi, tanya jawab dan diskusi dengan Kepala Sekolah dan guruguru SMP Negeri 2 Baso. Hasil diskusi menjadi dasar dan komitmen dalam melaksanakan kegiatan bimbingan teknis pengembangan perangkat pembelajaran berbasis keterampilan abad-21 dalam rangka penerapan program kurikulum merdeka belajar. Tahap observasi dan diskusi dilakukan untuk mensosialisasikan pengetahuan mengenai kurikulum merdeka belajar, keterampilan abad-21, dan bentuk perangkat pembelajaran yang mengintegrasikan keterampilan abad-21 di dalam kegiatan pembelajaran. Kegiatan ini dilaksanakan dengan metode diskusi dan demonstasi. Kepala Sekolah SMP Negeri 2 Baso mensosialisasikan kepada calon peserta bimbingan teknis untuk mempersiapkan keperluan dalam mengem bangkan perangkat pembelajaran yang dalam hal ini khusus RPP.

\section{Tahap Persiapan Pelaksanaan}

Tahap persiapan pelaksanaan kegiatan terdiri dari pengurusan perizinan pelaksanaan kegiatan pendampingan, serta mempersiapkan alat dan bahan pendukung untuk pelaksanaan bimbingan teknis pengembangan perangkat pembelajaran berbasis keterampilan abad-21. Selain itu, penulis juga melakukan persiapan materi tentang pengembangan perangkat pembelajaran, kurikulum merdeka belajar dan keterampilan abad-21 (keterampilan 4C), dan pengembangan perangkat pembelajaran berbasis keterampilan abad-21. Selain itu, persiapan instrumen yang akan digunakan untuk pengumpulan data selama kegiatan juga dilakukan.

Kegiatan dilakukan dengan metode diskusi anggota peneliti terkait perangkat pembelajaran keterampilan abad-21 dan konsep kurikulum merdeka belajar dan keterampilan abad-21 serta mekanisme pelaksanaan bimbingan teknis di lapangan. Hasil dari tahap persiapan ini adalah bahan materi presentasi untuk masing-masing 
materi dan contoh RPP berbasis keterampilan abad-21 (keterampilan 4C). Di lain sisi, Kepala Sekolah SMP Negeri 2 Baso Kabupaten Agam Sumatera Barat mempersiapkan tempat dan fasilitas pendukung kegiatan, serta hal-hal terkait administrasi seperti undangan peserta bimbingan teknis.

\section{Tahap Pelaksanaan Kegiatan}

Tahap pelaksanaan merupakan tahapan kegiatan bimbingan teknis pengembangan perangkat pembelajaran berbasis keterampilan abad-21 dalam rangka penerapan program merdeka belajar. Metode yang digunakan dalam pelaksanaan kegiatan bimbingan teknis adalah presentasi, demonstrasi, tanya jawab, diskusi, dan penugasan.

Pelaksanaan bimbingan teknis pengembangan perangkat pembelajaran mencakup: 1) melakukan pretes untuk menge tahui pengetahuan peserta terkait kurikulum merdeka belajar dan keterampilan abad-21, 2) mempresentasikan materi terkait perangkat pembelajaran, kurikulum merdeka belajar dan keterampilan abad-21 (keterampilan 4C), dan pengembangan perangkat pembelajaran berbasis keterampilan abad-21, 3) memberikan contoh perangkat pembelajaran berbasis keterampilan abad-21, 4) membimbing peserta dalam mengembangkan perangkat pembelajaran berbasis keterampilan abad-21. 5) mengarahkan dan memberi tugas kepada peserta untuk menyelesaikan draf perangkat pembelajaran berbasis keterampilan abad-21, 6) mempresentasikan produk bimbingan teknis pengembangan perangkat pembelajaran berbasis keterampilan abad-21, dan 7) memberikan postes setelah bimbingan teknis.

\section{Tahap Evaluasi Pelaksanaan}

Evaluasi dilakukan untuk menilai kegiat an yang telah dilaksanakan. Evaluasi dilakukan terhadap hasil kegiatan bimbingan teknis untuk menilai penguasaan dan pengetahuan peserta dan perangkat pembelajaran berbasis keteram pilan 4C yang dihasilkan peserta. Metode yang dilakukan pada tahap evaluasi adalah diskusi.

Data hasil penelitian diperoleh dari penggunaan beberapa instrumen penelitian, yaitu angket tanggapan guru terhadap kegiatan yg dilaksanakan, serta hasil pretest dan posttest. Hasil pretest dan postest digunakan untuk mendapatkan data terkait pemahaman peserta tentang kurikulum merdeka belajar dan keterampilan abad-21 sebelum dan setelah kegiatan bimbingan teknis. Data yang didapatkan dalam kegiatan bimbingan teknis dianalis secara kuantitatif menggunakan analisis statistik deskriptif, uji normalitas dan homogenitas data, dan uji parametrik/non parametrik yang sesuai untuk melihat keefektivitas pelaksanaan bimbingan teknis. Hasil evaluasi yang didapat digunakan sebagai tindak lanjut dalam kegiatan lain yang relevan dengan pengembangan kegiatan pengembangan perangkat pembelajaran berbasis keterampilan abad-21 dalam rangka penerapan program merdeka belajar.

\section{HASIL DAN PEMBAHASAN}

Berdasarkan hasil observasi dan diskusi yang dilaksanakan di sekolah diperoleh beberapa permasalahan yang perlu diselesaikan (a) Rendahnya pengetahuan guru tentang keterampilan abad 21, (b)Belum tersedianya RPP yang menerapkan keterampilan abad 21 di dalamnya, (c) Beragamnya format RPP satu lembar yang beredar sehingga guru kebingungan memilih format yang benar dan (d). Kesulitan guru dalam penerapan langkah pembelajaran yang tertulis dalam RPP karena kurang sesuai dengan kondisi peserta didik. Dari hasil observasi dan diskusi, maka dirancanglah bentuk kegiatan dan materi yang akan disampaikan dalam kegiatan bimbingan.

Pada tahap persiapan, penulis menyusun materi tentang pengembangan perangkat pembelajaran, kurikulum merdeka belajar dan keterampilan abad-21 (keterampilan 4C), dan pengembangan perangkat pembelajaran berbasis keterampilan abad-21. Selanjutnya, penulis mempersiapkan contoh RPP yang akan dikembangkan dimana didalamnya memuat komponen keterampilan abas 21 (keterampilan 4C). Selain itu, penulis juga mempersiapkan instrumen yang akan digunakan untuk pengumpulan data selama kegiatan juga dilakukan berupa lembar pretest dan posttest.

Tahapan pelaksanaan dibagi menjadi beberapa pertemuan, yang terdiri dari kegiatan pendampingan 1 , kegiatan mandiri 1 , kegiatan mandiri 2, dan kegiatan pendampingan 2 .

a. Kegiatan pendampingan 1

Tahap ini diawali dengan pemberian pretest tentang konsep keterampilan abad 21 dan perangkat pembelajaran. Selanjutnya, kegiatan dilanjutkan dengan pemberian 
materi tentang konsep keterampilan abad 21, kurikulum merdeka belajar, dan pengembangan perangkat pembelajaran. Kemudian, pada tahapan ini diberikan pemaparan dan diskusi tentang format RPP satu lembar yang akan dikembangkan.

b. Kegiatan Mandiri 1

Pada kegiatan ini guru mengembangkan RPP untuk satu kali pertemuan. Kegiatan pengembangan ini dimulai dengan menganalisis kelemahan dan kekurangan dari RPP yang telah dirancang sebelumnya dan dibuat sesuai dengan format RPP berbasis keterampilan abad 21 yang telah diberikan pada kegiatan pendampingan 1 . Ketarampilan abad 21 yang dibuat berupa keterampilan $4 \mathrm{C}$ dan dituliskan secara jelas pada langkah pembelajaran. Kemudian, hasil RPP yang telah dibuat peserta dikumpulkan untuk dianalisis kelengkapan komponennya.

c. Kegiatan Mandiri 2

Pada tahapan ini, guru merevisi RPP yang dibuat pada kegiatan mandiri 1 sesuai dengan saran dan masukan tim. Kegiatan disertai dengan diskusi terhadap kendala dalam penyusunan RPP satu lembar tersebut.

d. Kegiatan Pendampingan 2

Tahapan ini merupakan tahapan akhir dari kegiatan pelaksanaan. Pada kegiatan ini guru mempresentasikan setiap RPP yang telah dikembangkannya. Kegiatan dilanjutkan dengan diskusi dan masukan sebagai refleksi pelaksanaan kegiatan. RPP yang telah dikembangkan selanjutnya digunakan dalam pembelajaran dan dibuat juga untuk materi lainnya. Kegiatan ini ditutup dengan pemberian posttest kepada guru-guru yang terlibat.

Tahapan terakhir dari penelitian ini adalah tahapan evaluasi kegiatan. Data evaluasi diperoleh dari angket tanggapan guru terhadap kegiatan serta hasil pretest dan posttest terkait pemahaman guru terhadap keteampilan abad 21 dan pengembangan perangkat pembelajaran berbasis abad 21 .

Analisis data dilakukan untuk melihat pengaruh kegiatan bimbingan teknis pengembangan perangkat pembelajaran berbasis keterampilan abad-21 dalam penerapan program merdeka belajar berarti atau tidak. Efektivitas kegiatan bimbingan teknis ditentukan dengan membandingkan penguasaan peserta sebelum melakukan kegiatan dengan sesudah melakukan kegiatan. Hasil analisis statistik deskriptif pretes dan postes dapat dilihat pada Tabel 1 .

Tabel 1. Hasil Analisis Statistik Deskriptif

\begin{tabular}{clcc}
\hline \multirow{2}{*}{ No } & \multicolumn{1}{c}{$\begin{array}{c}\text { Statistik } \\
\text { Deskriptif }\end{array}$} & \multicolumn{2}{c}{ Nilai } \\
\cline { 3 - 4 } & Pretes & Postes \\
\hline 1 & n & 16 & 16 \\
2 & Mean & 39,29 & 71,79 \\
3 & Median & 37,5 & 70 \\
4 & Std. Deviation & 14,92 & 10,67 \\
5 & Variance & 222,53 & 113,87 \\
6 & Range & 50 & 40 \\
7 & Minimum & 15 & 50 \\
8 & Maximum & 65 & 90 \\
\hline
\end{tabular}

Berdasarkan data pada Tabel 1 dapat dijelaskan parameter nilai minimum dan maksimum, nilai rata-rata, dan standar deviasi dari hasil pretes dan postes yang diberikan kepada 16 orang guru di SMP Negeri 2 Baso Kabupaten Agam. Nilai minimum dan maksimum pretes masing-masing adalah 15 dan 65 , sedangkan nilai minimum dan maksimum postes masing-masing adalah 50 dan 90 . Nilai rata-rata dan standar deviasi untuk pretes masing-maing adalah 39,29 dan 14,92, sedangkan nilai rata-rata dan standar deviasi untuk postes masing-masing adalah 71,79 dan 10,67. Berdasarkan data hasil analisis statistik deskriptif yang dilakukan dapat dinyatakan bahwa nilai rata-rata postes cenderung lebih tinggi dari nilai rata-rata pretes.

Penarikan kesimpulan diawali dengan uji hipotesis secara statistik. Hal ini bertujuan untuk mengetahui apakah hipotesis ditolak atau diterima, yakni apakah terdapat pengaruh yang berarti kegiatan bimbimbingan teknis pengembangan perangkat pembelajaran berbasis keterampilan abad-21 dalam penerapan program merdeka belajar terhadap guru-guru di SMP Negeri 2 Baso Kabupaten Agam atau tidak. uji normalitas dan homogenitas data dilaksanakan sebelum uji hipotesis. Uji normalitas dilakukan menggunakan uji Shapiro Wilk dengan SPSS pada taraf nyata 0,05 . Hasil uji normalitas menunjukkan nilai signifikansi pretes sebesar 0,733 dan nilai post tes adalah 0,892 . Karena nilai signifikansi tersebut lebih besar dari 0,05 maka dapat disimpulkan bahwa data nilai pretes dan postes terdistribusi normal.

Selanjutnya, uji homogenitas menggu nakan uji Anova dengan SPSS pada taraf nyata 0,05 . Hasil uji homogenitas menunjukkan 
signifikansi data adalah 0,182. Hal ini menunjukkan bahwa nilai pretes dan postes mempunyai variansi yang homogen. Berdasarkan hasil analisis yang dilakukan dapat diamati bahwa pretes dan postes terdistribusi normal dan mempunyai variansi yang homogen atau sama. Uji statistik yang cocok untuk sifat data ini adalah uji paired sample t-test atau uji kesamaan dua sampel berpasangan.

Hasil uji paired sample t-test yang diperoleh memiliki signifikansi sebesar 0,00. Data menunjukkan hipotesis diterima, artinya ada pengaruh yang signifikan kegiatan bimbingan teknis pengembangan perangkat pembelajaran berbasis keterampilan abad-21 dalam penerapan program merdeka belajar bagi guru-guru SMP Negeri 2 Baso Kabupaten Agam.

Berbagai analisis yang dilakukan mengindikasikan bahwa kegiatan bimbingan teknis pengembangan perangkat pembelajaran berbasis keterampilan abad-21 dalam penerapan program merdeka belajar memberikan pengaruh yang berarti terhadap pengetahuan guru-guru SMP Negeri 2 Baso Kabupaten Agam.

Tanggapan kepuasan guru-guru dalam penelitian ini dapat diamati pada Gambar 2.

\section{Pengaruh Bimbingan Teknis terhadap Guru}

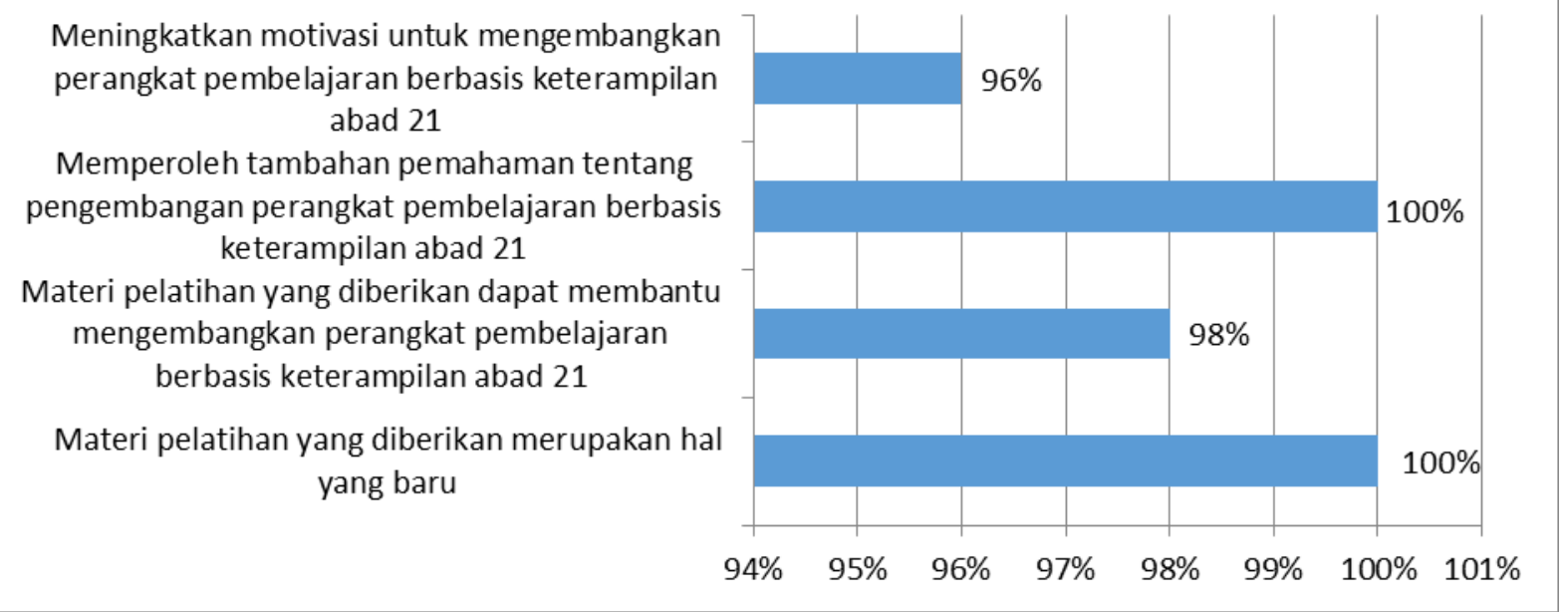

\section{Gambar 2. Hasil Angket Tanggapan Guru}

Berdasarkan hasil analisis terhadap angket tanggapan dari guru diketahui bahwa kegiatan bimbingan teknis ini dapat memotivasi dan mengarahkan guru untuk membuat RPP satu lembar yang berbasis keterampilan abad- 21 . Kegiatan ini membantu peserta memahami esensi dari keterampilan abad-21. Sebagai hasilnya peserta dalam hal ini guru dapat menguasai dan menulis perangkat pembelajaran keterampilan abad-21, yang dibuktikan dengan sudah terkumpulnya 14 perangkat pembelajaran berupa RPP satu lembar oleh guru-guru yang memuat keterampilan abad-21 dan konsep merdeka belajar setelah dilakukannya kegiatan pendampingan. Hasil ini relevan dengan hasil penelitian Sopiah (2019) yang mengemukakan bahwa kegiatan pendampingan dapat membantu peserta dalam memahami dan membuat perangkat pembelajaran seperti modul, LKS, dan media pembelajaran.

Kegiatan pendampingan bagi guru-guru ini juga efektif dalam meningkatkan pemahaman guru-guru untuk menyusun dan mempersiapkan perangkat pembelajaran berupa RPP yang sesuai dengan keterampilan abad-21 dan konsep merdeka belajar di sekolah. Hal ini ditunjukkan dari adanya peningkatan pemahaman guru-guru dari nilai pretes dan postes yang diberikan selama kegiatan. Hasil ini juga sesuai dengan hasil penelitian oleh Asrizal, dkk. (2020) yang menemukan bahwa kegiatan pendampingan bagi guru-guru efektif dalam meningkatkan kompetensi guru.

\section{KESIMPULAN}

Kegiatan bimbingan teknis terbukti dapat meningkatkan pemahaman peserta terhadap pengembangan perangkat pembelajaran berbasis keterampilan abad-21 dan program merdeka belajar di sekolah. Hasil ini didasarkan pada peningkatan skor pretes dan postes guru-guru SMP Negeri 2 Baso Kabupaten Agam yang diperoleh. 


\section{DAFTAR PUSTAKA}

Afriani, A. 2016. Upaya Meningkatkan Kompetensi Guru dalam Memanfaatkan Lingkungan Sebagai Sumber Belajar Melalui Peningkatan Efektivitas Pendampingan Guru IPA di SMP se-Kota Gorontalo. Jurnal Entropi, 11(2): 226231.

Ahmad, G. 2020. Mengembangkan Rencana Pelaksanaan Pembelajaran (RPP) Abadi 21 melalui Individual Conference. Syntax Literate : Jurnal Ilmiah Indonesia, 5(1): 1-8.

Asrizal, dkk. 2020. Studi Pendampingan Pengembangan Bahan Ajar Tematik Terintegrasi Literasi Baru dan Literasi Bencana pada Guru IPA Kabupaten Agam. Jurnal Eksakta, Vol 4 Tahun 2020.

Bamalli, H.S. 2013. Competencies and Strategies for the Teaching of $21^{\text {st }}$ Century Learners in Vocational Home Econo mics Education. Journal of Educational and Social Research, 3 (9) : 105-108.

Baro'ah, S. 2020. Kebijakan Merdeka Belajar Sebagai Strategi Peningkatan Mutu Pendidikan. Jurnal Tawadhu, 4(1), 10631073.

Chen, H.L.S., \& Huang H.Y. 2017. Advancing $21^{\text {st }}$ Century Competencies in Taiwan. National Taiwan Normal University: 121.

Faiz, A., \& Kurniawaty, I. 2020. Konsep Merdeka Belajar Pendidikan Indonesia dalam Perspektif Filsafat Progresivisme. Konstruktivisme : Jurnal Pendidikan dan Pembelajaran, 12 (2): 155-164.

Griffin, P., \& Care, E. 2015. Assessment And Teaching of 21st Century Skills: Methods and Approach. Dodrecht:Springer Business Media

Hendra, Suwardana. 2017. Revolusi Industri 4. 0 Berbasis Revolusi Mental, JATI UNIK, 1(2): 102-110. https://referensi.data.kemdikbud.go.id/index11_ smp.php?kode $=080100 \&$ level $=2$

https://puspendik.kemdikbud.go.id/hasil-un/ Meylani, V., Putra, R. R., \& Ardiansyah, R. 2018. Pengembangan Lembar Kerja Peserta Didik (LKPD) dan Pengayaan Materi Biologi Dalam Mata Pelajaran IPA Sesuai Kurikulum Nasional Bagi Guru IPA di Lingkungan SMP / Sederajat SeKota Tasikmalaya. Jurnal Pengabdian Siliwangi, 4(1), 13-17.

Mualifah,I. 2013. Progresivisme John Dewey dan Pendidikan Partisipatif Perspektif Pendidikan Islam. Jurnal Pendidikan Agama Islam, 01(01): 102-121.

Riyanto, A. 2018. Kenali 4 C, Empat Keterampilan Abad 21 yang Harus Dimiliki Peserta Didik. https://www.amongguru. com/kenali-4-cempat-keterampilan-abad-21-yang-harusdimiliki-peserta-didik/

Riyanto, A. 2019. 4 Pokok Kebijakan Program Merdeka Belajar dari Mendikbud. https://www.amongguru.com/4-pokokkebijakan-program-merdeka-belajar-darimendikbud/

Sopiah, dkk. 2019. Pelatihan dan Pendampingan Penyusunan Bahan Ajar Bagi Guru SMA 5 Kediri. Jurnal Karinov, Vol 2 Tahun 2019

Superfine, A.C. 2008. Planning for mathematics instruction: a model of experienced teachers' planning processes in the context of a reform mathematics. Jurnal of The Mathematics Educator, 18, 11-22.

Trilling, B., \& Fadel, C. 2009. $21^{\text {st }}$ Century Skills: Learning for Life in Our Times. In Jossey-Bass $\left(I^{\text {st }} \quad\right.$ ed. $)$. https://doi.org/978-0-470-47538-6.

Zubaidah, S. 2019. Mengenal 4C:Learning and Innovation Skills Untuk Menghadapi Era Revolusi Industri 4.0.https://www. research gate. net/ publication/ 332469989_Mengenal_4C_Learning_And Innovation_Skills_Untuk_Menghadapi_ Era_Revolusi_Industri_40_1 